綜説

\title{
ダィアフラム型真空計につマて
}

\author{
塚越修* - 桐谷仁*
}

(昭和 39 年 7 月 5 日受理)

\section{The Diaphragm Manometer}

\section{Osamu TSUKAKOSHI and Masashi KIRIYA}

(Japan vacuum Engineering Co. Ltd. Yokohama, Japan)

\section{1. まえがき}

薄いダイアフラムの両面に加はる压力に差がある場 合、ダイアフラムは压力差に忘じてたわむてあらう。こ のたか文何らかの方法によって検出して、気体の圧力 差また注全生を則定しようとする試みは1940年頃から 始まった上考えられる。初期にはダイアフラムの変位を 光学系を朋いて検出する試みもなされたが、やがて、ダ イアフラムに近接して設けられた平行電極とダイアフラ ムとの留の電気容量の変化として検出する方法が有効で あることが灾らられるようになった。まず、振動あるい は運動によった影響を受けない応答速度の早い小さな感 压素子を思い曲りやすよ侧定ケーブルを用いて圧力を

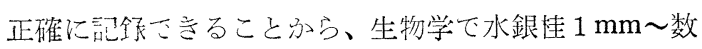
百mmの液体の上力を吃軫するのに適した則定器として 研兊され、引心、众体の種類に関係なく全爪を示すこと から、留星分析胡の資料父体導入系て $10^{-3}$ Torr 1 Torr の食䊀ガスの压の則定に用いられるようになり、

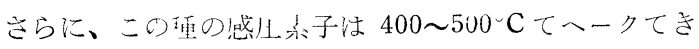
るような挴造に方ることも可能であるのて、超高真空系 て純 な父体の上力在測定しようとするときなどに用い ら礼るミえになった。

ダイアフラムの变似を娭出与る少式としては、その

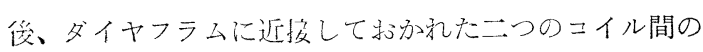
相互インダクタンスの昰化、あるいはダイアフラムの変 位によって证道の变るコイルと固定コイルとの間の㥵互 インダクタンスの糸化として愉出する方式、岕よひ、ダ

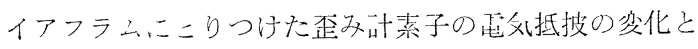

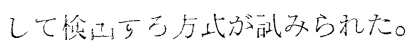

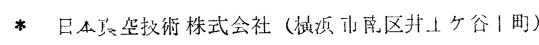

これらのダイアフラム真空部の特徴としては、

(1) 10-3 Torr 心ら大父压までの範囲て、父体の種類に 䦤係なくその全正めるいは压力差を測定することがで きる。

（2）污れによって感度の变化することがなく、丽的性を もつ構造にすることも可能でる。

（3）気体の压力を電気的信号としてとり出すのて、遠隔 測定、記録を行い、あるいは真空系の自動制御化に役 立たせることも可能である。

ダイアフラムの変形を検出する方式としては、この他 に磁歪効果を利用するもの等があり、また、ダイアフラム の変形学機械的に掋大して指邻をふらせる型もあるが、 ここで、、電爻容量、相互インダクタンス、電気抵抗の 変化として検出する型のみについて将えることにする。

\section{2.ダイアフラムの压力差による翌形}

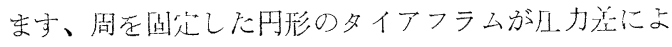

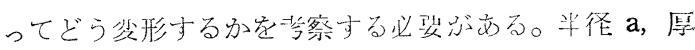
されの多アフラムに、几力庄pによつて生しる変形 を次のように分けて考えることがてきる。籍 1 図に示す ように扳の厚みの1 $\frac{1}{2}$ ところを通る中心面 (mid-plane) $\mathrm{MM}^{\prime}$ を艺える。タイアフラムの尜形は $\mathrm{MM}^{\prime}$ の伸ひ

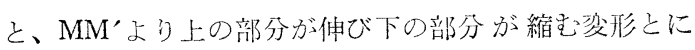
分けて考えることがてき、前者を便宜上「ダイアフラム の伸ひ尖形」、後者を「タイアフラムのれれみ」と称生 るこに可る。

ダイアフラムの中心が微少量 $\delta a$ だけ会位したとする と、ダイアフラムの伸ひは蛙よ卡

$$
2\left(a \vee 1+\delta^{2}-a\right) \simeq i^{2} a
$$

となり、二次の改分小!なる。ダイアフラムの糸形がご 


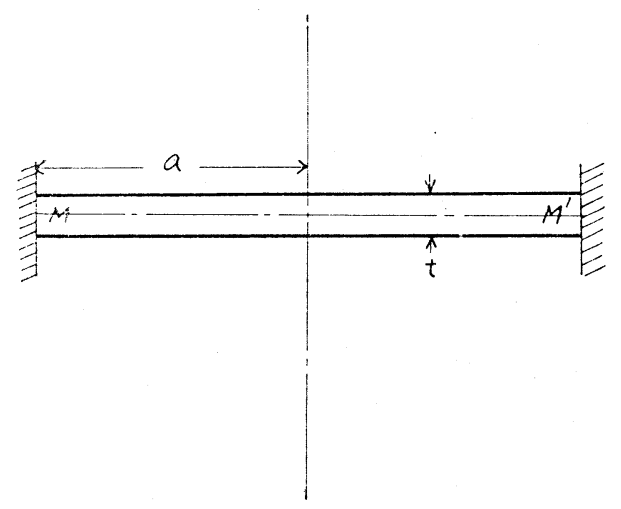

箁 1 図 周を固定したダイアフラム

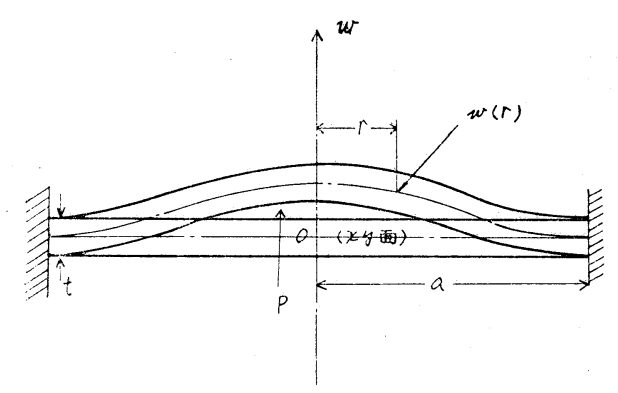

第 2 図 ダイアフラムの变形一薄板近似

くわづかである場合には、ダイアフラムのたわみだけ を考慮すればよく、ダイアフラムの厚さが半径にくらべ て非常に小さく、かつ、変形が大きいときには、伸び変 形の夕を考慮すればよいことになる。弾性体論ではこの 二つの場合が厳密に解かれていて、前者を薄板近似 (Thin plate Approximation)、後者を薄膜近似 (Mem-

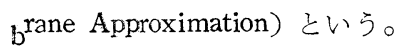

\section{1 薄板近似}

一様な物質でできた一様な厚さの板を考光、第 2 図に 示すように、歪を受けないときの中心面を $x y$ 面とし、 ダイアフラムの中心を通り $x y$ 面に垂直に $w$ 軸定とる。 板がたわ导壮あい、板の中心面の各部分の変位を $w(x$, y) とする之、板の各部分のポテンシアル・エネルギー 洼算位面皘あたり

$$
V=\underset{24\left(1-t^{2}\right)}{E}-\left\{\left(\frac{1}{R_{1}}+\frac{1}{R_{2}},-\frac{2(1-\sigma)}{R_{1} R_{2}}\right\}\right.
$$

である。ここに $R_{1}, R_{2}$ 注曲面の主曲率半径であり、 E㳊板つくる物質のヤング率、 $\sigma$ そのポアッソン比で

$$
\left.\begin{array}{c}
\text { あるここに } \\
\frac{1}{R_{1}}+\frac{1}{R_{2}}=\frac{\partial^{2} w}{\partial x^{2}}+\frac{\hat{o}^{2} w}{\partial y^{2}}, \\
\frac{1}{R_{1}{ }_{2}}=\frac{\hat{o}^{2} w}{\partial x^{2}} \frac{\partial^{2} w}{\partial y^{2}}-\left(\frac{\hat{o}^{2} w}{\partial x \partial y}\right)^{2}
\end{array}\right\}
$$
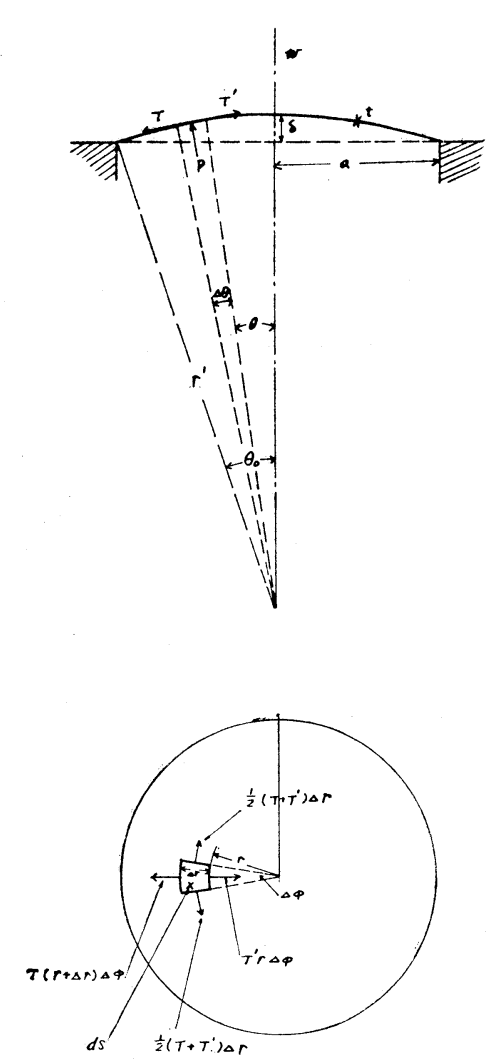

第3図 ダイアフラムの変形一薄膜近似

一様な压力 $p$ を受けて中心面が $u(x, y)$ という形に 変形して平衡したとすると、面素片 $\delta S$ に作用する $w$ 方 向の力は $\left(p-\frac{\partial V}{\partial w}\right) \delta S$ となり、平衡条件は、仮想变 位の原理から

$$
\iint(p \delta w-\delta V) d S=0
$$

(1)に(2)定代入乙周が固定されているという条件を入れて 変形すると

$$
\begin{aligned}
\iint \delta V d S & =\frac{E t^{3}}{12\left(1-\iota^{2}\right)} \iint \delta w d S\left(\frac{\delta^{4} w}{o \lambda^{4}}\right. \\
& \left.+2 \frac{\delta^{4}}{\partial \iota^{2}} \frac{v}{\partial y^{2}}+\frac{\delta^{4} w}{\partial y^{4}}\right) \cdots \cdots \cdots(4)
\end{aligned}
$$

となる。従つて

$$
\frac{\hat{o}^{4} w}{\partial x^{4}}+2 \frac{\hat{o}^{4} w}{\partial x^{2} \partial y^{2}}+\frac{\hat{c}^{4} w}{\partial y^{4}}=p / \frac{E t^{3}}{12\left(1-\sigma^{2}\right)}
$$

を得る。 $x y$ 面をガウスの平面とすると(5)は

$$
\begin{aligned}
& \nabla^{4} w=16 \hat{o}^{4} w / \partial Z^{2} \partial Z^{* 2}=p / D \\
& D=\frac{E t^{3}}{12\left(1-v^{2}\right)}
\end{aligned}
$$
引。 


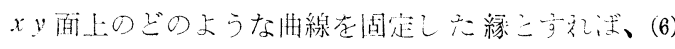
の式夌解くこととができるかといら問題注二、三の応用

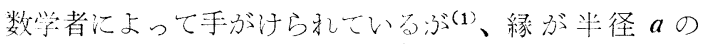
円である場合を解くと、中心怘y ○場所の变位法

$$
w(r)=\frac{p\left(r^{2}-a^{2}\right)^{2}}{\frac{16 E t^{3}}{3\left(1-\iota^{2}\right)}}
$$

中心の変位は

$$
w_{0}=\frac{1}{\frac{16 i}{3(1-, 2)}} \frac{a^{4}}{i^{3}}
$$

となる。どの值の变位末で(8)が使光るか法、ダイアフラ 么の伸び变化も亦わせて考光た一般の解召得られなけれ ば判定子ることはできないが、実測された例では、 $a=$ $0.6 \mathrm{~cm}, t=0.022 \mathrm{~cm}$ のダイアフラムにつき、 $w_{0}=0.001$ $\mathrm{cm}$ 安で薄板近似が正確に成立与ること汃破好られてい る。

\section{2 薄膜近似}

ダイアフラムが非常に薄く、正力差が相当大きくてダ イアフラムがかなり変形する場合にはダイアフラムの伸 び変形に刘応する応力が、たわ文变形汇対灾与る応力に くらでてずっと大きくなる。後者を無視できるとした場 合溥膜近似となり、周を固定された円形の薄膜の圧力差

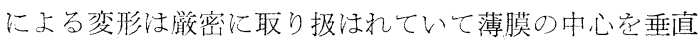
に貫く直線を刘称軸之专る廻転拋物面之なることが知ら れているが、さらにこれを球面で近似して下洼のように 概算占ることができる。

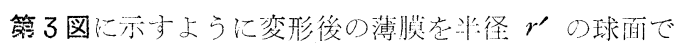
近似寻ると溥脱の伸びの霜の平均做は

$$
\frac{\overline{\Delta l}}{l}=\frac{r^{\prime} 2^{\prime}{ }_{0}-2 a}{2 a}=\frac{r^{\prime}\left(2{ }^{\prime} 0-2 \sin ^{\prime} 0_{0}\right)}{2 r^{\prime} \sin \theta_{0}} \simeq \frac{1}{6} \theta_{0}^{2}
$$

荧汇注たらく張力の平均值は

$$
T=E \stackrel{\Delta l}{l} \cdot t
$$

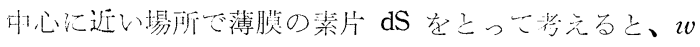
輎化垂淔な方向での力の鹆り合いから $T=T^{\prime}$ が得ら れ、w軸方向の力の釣り合いを考えると

$$
\begin{aligned}
& T(r+\Delta r) \Delta \varphi \sin (\theta+\Delta \theta)-T r \Delta \varphi \sin \varphi \\
& =p \cos \theta r \Delta \varphi \Delta r
\end{aligned}
$$

$\theta \ll 1$ すると

$$
T=\frac{p r^{\prime}}{2}=\frac{p}{2}-\frac{a}{\theta_{0}}
$$

之いう関係が得うれ、さらに $T=T$ 上方るま

$$
\begin{aligned}
& \mathrm{r}_{0}=\left(\frac{3 p a}{E t}\right)^{\frac{1}{3}} \\
& \frac{\overline{\Delta l}}{l}=-\frac{1}{6}\left(\frac{3 p a}{E t}\right)^{\frac{2}{3}} \\
& \hat{j}=\frac{1}{2} a\left(\frac{3 h z}{E i}\right)^{\frac{1}{3}}
\end{aligned}
$$

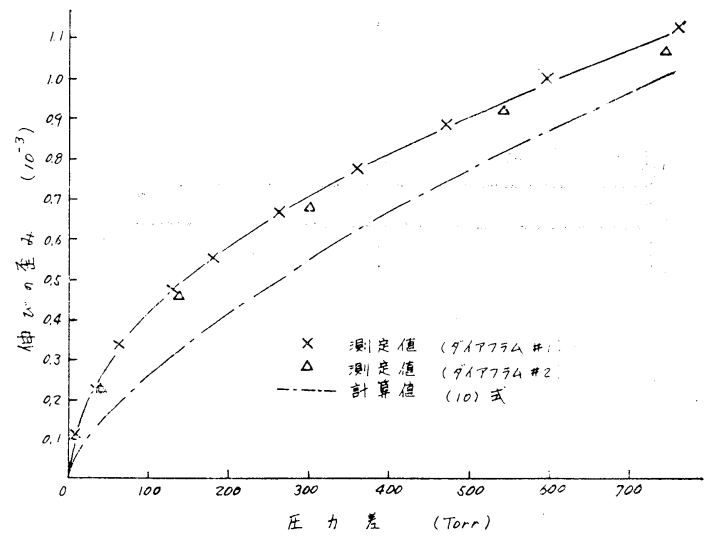

第 4 ダイアフラムの伸びの歪み一実刞值と薄膜近 似による計算值との比較

といら関倸が得られる。第 4 図に $t=0.05 \mathrm{~mm}, a=15$ $\mathrm{mm}$ のインパールのダイアフラムについて、查み計で湘 定した中心部の歪 $\frac{\Delta l}{l}$ と、 $E=1.9 \times 10^{12} \mathrm{dyne} / \mathrm{cm}^{2}$ と して(10)から計算した値とを比較してみた。

\section{3. 電気容量の变化こして検出するダイアフ ラム真空計の測定子}

ダイアフラムに近接して、平行におかれた電極とダイ アフラムとの間の電気容量の変化を測定してダイアフラ ムの変形在梌出与る型には、変位法(deflection method) 々零位法 (Zero method) の二つの方式が弯吕。变位法 ではダイアフラムのたねみによって生じた容量の変化の 大さ走測ってダイアフラムに加わる生を測定し、零位法 では压に合うような静電力をダイアフラムに加えて、 丁度電気容量の変化が零になるようにし、欲合のときの 静電力から压力を測らうとするものである。

\section{1 变位法}

変位法による場合、測定子の設計に必要なことは、測 定しょうとする圧力変化に対して、用意された測定回路 に必要な大さの、容量変化が生じるようにすることであ る。Lilly等 ${ }^{(2)}$ に從ってこの問題を考えてみることにす る。

この型では、一般にダイアフラムのたれダ注小く、薄 板近似で取り扱うことができ、圧力差 $p$ のときのダイ アフラムの形は(8)であらわされる。ダイアフラムと平 行雪極との距離注電極の直径にくらべて極めて小いの で、両者の間の静電容量は下記のように計算できる。

電極面上に、中心軸 $w$ との交点を中心とする巾の無 限に小い環它考光，これに対応するダイアフラム上の環 


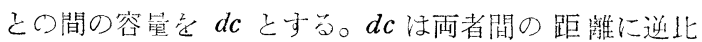
例し、環の面積 $2 \pi r d r$ に比例与る。電㥛とダイアフラ ム上の間の電父容量は $\int_{0}^{\mathrm{B}} d c$ として求めることができる

(但し $B$ は電極の半径)。電惯の半径と電極間の空腺 こつ比湴通 200〜2000 ごるから、端縁効果は無視 七学。

\section{i) 圧力差 0 のとき}

羿行電標・ダイアフラム間の空鄀 $S \mathrm{~cm}$ 霆気容画

$$
C_{0}=-\begin{gathered}
B^{2} \\
4 S
\end{gathered} \quad \mathrm{~cm}
$$

ii) 圧力差 $p$ のとき

ダイアフラムの各部分の変位 $w(r)=K p\left(r^{2}-a^{2}\right) / t^{3}$ 但し $K=3\left(1-u^{2}\right) / 16 E$

中心.の变位 $w_{0}=w(O)=K p a^{4} / t^{3}$

電気容量

$C=\int_{0}^{B}-\frac{2 \pi r d r}{\pi\{S-w(r)\}}$

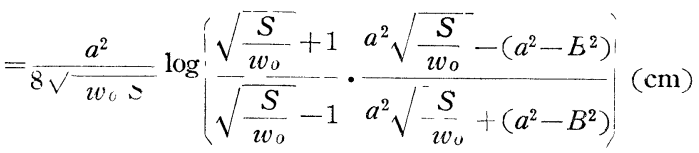
(11)

点斿

$N=(B / a)^{2}, \quad H=1-. N$

$u=w_{0} / S, \quad v=u^{\frac{1}{3}}$

こおいて変形すると、

$C=\frac{a^{2}}{4 \sqrt{-}-\overline{w_{v} S}} \tan h^{-1} v \cdot \mathrm{V} / 1-H u(\mathrm{~cm}) \cdots \cdots(12)$

となる。

次に感度の性刘值を論ずるために、性刘容量变化（容 量の变化分に比例する量） $s$ 它定義して考えてゆく。

$$
s \equiv\left(C-C_{0}\right), \frac{a^{2}}{4 S}=\frac{1}{v} \tanh ^{1} v N /(1-I H u)-N
$$

第 5 図に相詨容盐变化 $s$ と相刘变位 $u=w_{0} / S$ との関 係定あらす $(B / a=10$ 方）。

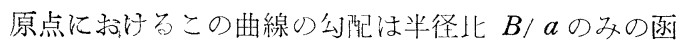
数となる。

$$
M=\left(-\frac{d s}{d u}\right)_{\iota=0}=1 / 3 \cdot\left(1-H^{3}\right)
$$

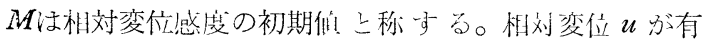
限の大さになった場命、ニつの相刘変倠感度定義与る ここができる。

$$
m=s / u
$$

立正制㥵效感度、

$$
n=\partial s / \partial u
$$

定正妸相対感度と定義する。

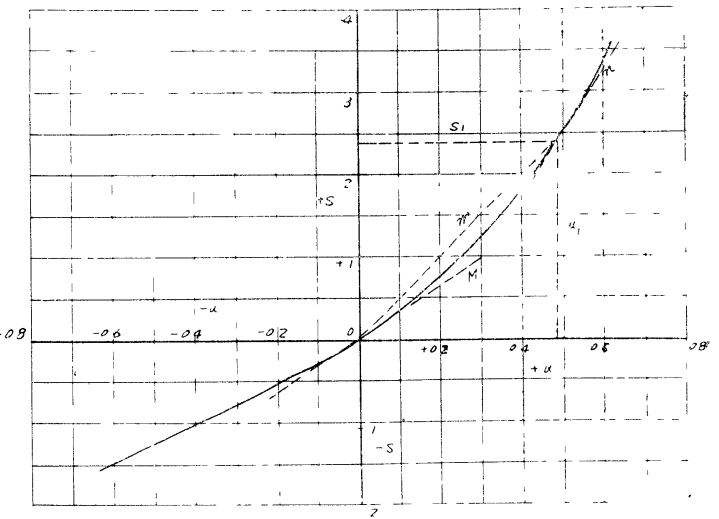

第 5 図 多イアフラムの相刘変借と相刘容昌変化と の閔係

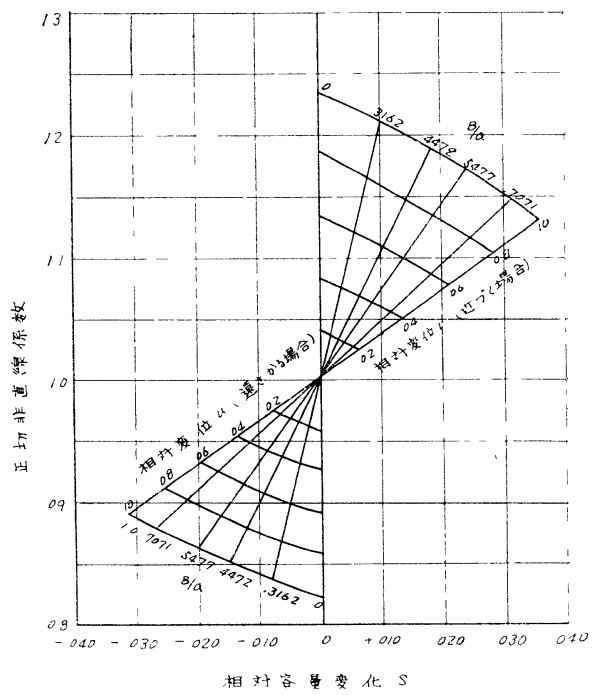

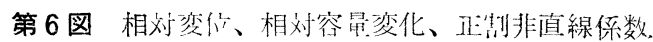
○閔係

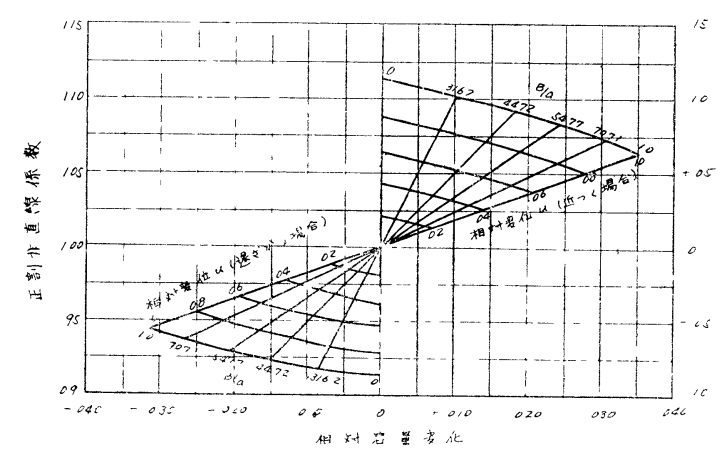

第 7 図 相对変位、相対容量炃化、正切非宜線係数の関菜 


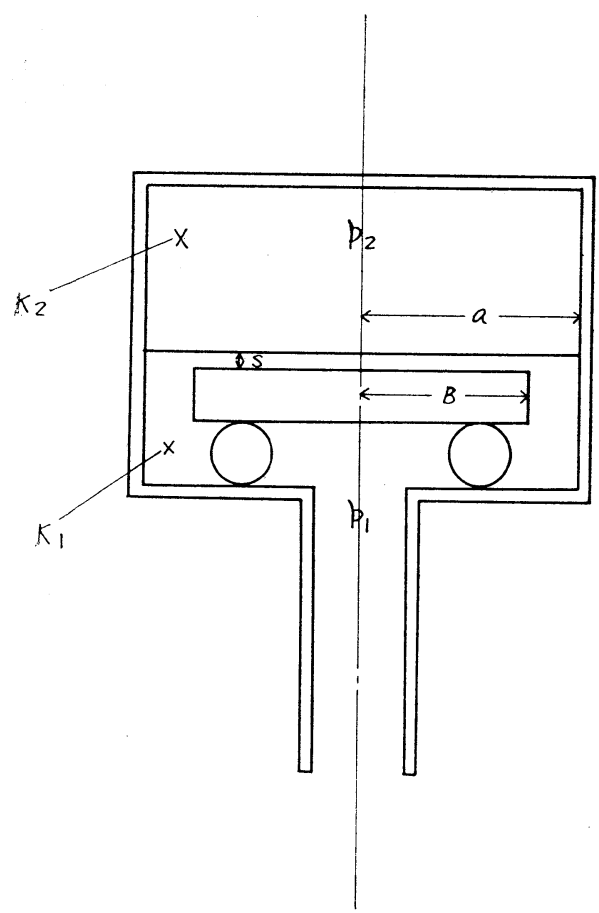

第 8 図 容量型洪定子一零位法 $(\leftrightarrow$ 。

測定子の非直線性は下記のような非直線性係数を定義 して議論ることができる。

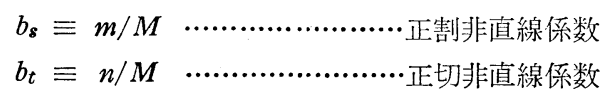

この二つの係数は、半径比 $B / a$ のきまった值に対して 定義され、 $u$ の函数である。

相対変位が 0 に近づくと、 $b_{s}, b_{t}$ は 1 に近づく。従 ってこの型の測定子が最も直線的であるのはダイアフラ ムの変位が電極間の空隌にくらベて非常に小さい場合で ある。ダイアフラムが固定電極に近づく場合には、非直 線係数は 1 より大きく、遠ざかる場合には 1 より小さく なる。第 6 図に $b_{s}$ と $s, B / a$ との関係、第 7 図に $b_{t}$ と $s, B / a$ との関係を示す。

絶対感度係数も正割および正切係数を定義することが できる。

絶対感度正割係数は電気容量変化と圧力差との比で

$$
\frac{C-C_{0}}{p}=\frac{s \cdot a^{2} / 4 B}{2 v_{0} / K a^{4} / t^{3}}=m K a^{6} / 4 \cdot t^{3} s^{2} \cdots \text { (14) }
$$

絶対感度の正切係数は圧力の変化によって電気容量の変 化する割合で

$$
\frac{\partial\left(\mathrm{C}-C_{0}\right)}{\partial p}=n K a^{6} / 4 t^{3} S^{2} \cdots \cdots \cdots \cdots \cdots \cdots(15)
$$

となる。以上の式及び抜から測定子の絶対感度、非直線 性等を知ることができる。

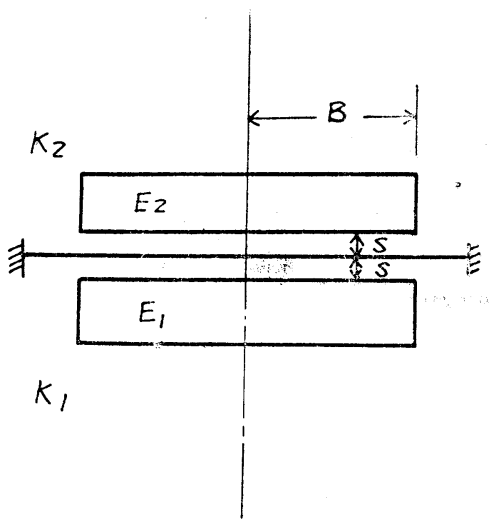

第 9 図 容量型測定子一零位法 $\Leftrightarrow$

\section{2 零位法 $^{(3)}$}

第 8 図に示すように、電極 $E_{1}$ を含主区画 $K_{1}$ 内门 圧力 $p_{1}$ が、ダイアフラムによって区切られた区画 $K_{2}$ 内 の圧力 $p_{2}$ より大きいとする。压力差 $p=p_{1}$ - $p_{2}$ によっ て、ダイアフラムは僅かながらたわむであらう。直流電 压 $U$ (補正電圧) を電極 $E_{1}$ とダイアフラムとの間に かけることによって、ダイアフラムを最初の静止位置に 引きもどすことができる。このようにダイアフラムがも との静止位置にもどったとき、次の関係が満足される。

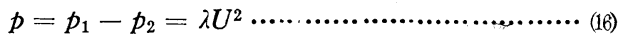

$\lambda$ はコンデンサーの幾何学的寸法によってきまり、

$$
\lambda=3.33 \frac{F^{2}}{S^{2} a^{2^{-}}} \cdot 10^{-10}\left(\begin{array}{c}
\text { Torr } \\
- \text { Volt }^{-}
\end{array}\right) \cdots \cdots \cdots \cdots \cdots \cdots \cdots(17)
$$

で与えられる。

第 9 図のように $K_{2}$ に第二の電極 $E_{2}$ 岁入れることに より、(16)を $U$ について一次の式にすることができる。 このとき、三つの電極には、ダイアフラムに対し最初一 定の電压 $U_{0}$ を与えておき、 $E_{1}$ の電圧を $U_{0}$ よりさらに

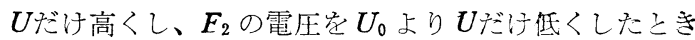
ダイアフラムがもとの静止位置に引きもどされたとする と、

$$
p=\lambda\left(U_{0}+U\right)^{2}-\lambda\left(U_{0}-U\right)^{2}=4 \lambda U_{0} U \cdots \cdots(18)
$$

を得る。こうして、最初の静止位置にもどったときのし の值をはかってpをもとめることができる。

零位法では圧力差 $p$ が数 Torr に達すると、電極 $E_{1}$ 之 ダイアフラムとの間に加えなければなら收静電圧が増大 することとあいまって、 $E_{1}$ とダイアフラムとの間に教 電が起り、ここで測定可能の最大压がきまることにな る。ただ、この限界より低い压ではダイアフラムの弾业 諸常数がゲーヂの感度に入って来ない点で、変位法にく らべてすぐれていると云える。 


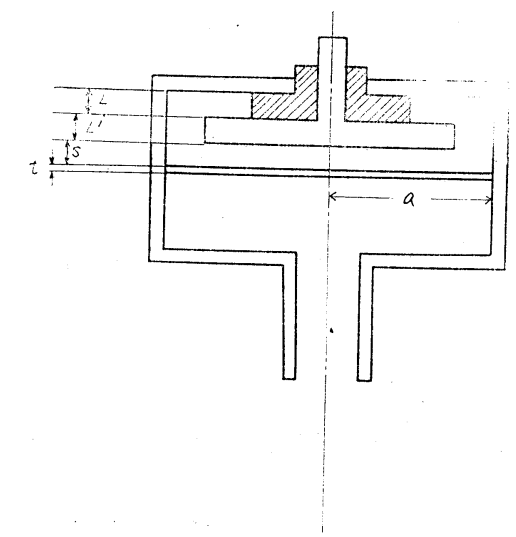

第10罗 容星型則定子の温度による影響

\section{3 容量型測定子の温度による影響}

容量型ダイアフラム真空計の測定可能な最小圧はダイ アフラムの弾性的性質の変化、あるいは履歴効果、電気 容量の凯小変化を測定することの固難さなどによってき まるものでなく、測定子の温度が变化することによって 測定子の内部に生ずる色々な変形によってきまるもので ある。

Pressey ${ }^{(4)}$ はこの問題它検討して、温度による容量の 変化率 $\alpha:$ は $10^{-4} /{ }^{\circ} \mathrm{C}$ 程度になるとの結諭老得た。

温度による容最の变化率としては次の二つの効果定考 えることができる。第一は、测定子の各部の熱膨『によ って、電極間の空陣そのものが変化することであり、第 二は、ダイアフラムの材質とダイアフラムを支える部分 との熱膨『係数が完全に等しくはないために生ずるたわ タ, (buckling) である。

第一の効果については、第10図のように、金属および

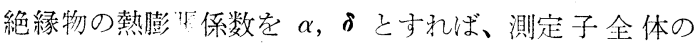
温度が一様に上昇するときは、

$$
\alpha_{\mathrm{c}}=\alpha-L(\alpha-\delta) / S
$$

となる。

第二の効果については、ダイアフラムとダイアフラム 甞支える部分との熱膨国係数の艺ととすると、温度 が $\triangle T^{\circ} \mathrm{C}$ だけ上昇したとき、熱的たわ友による中心点 の变位 $w_{1}$ 注、

$$
w_{1}=1.28 a \cdot \sqrt{\gamma \cdot \Delta T}
$$

以上の式から、絶縁物の厚さ $L$ と、ダイアフラムと ダイアフラム支持部との膨張係数の差 $\gamma$ はできるだけ 小さくしなければならぬことがわかる。

\section{4. 容量変化こして検出する型つ回路}

この型の回路には変位法によるものと零位法によるも の上がある。最初は変位法によるものから発達して来

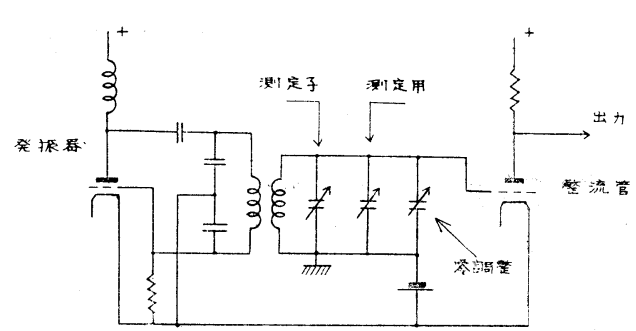

第11図 Brcokes-Smith による回路（变位法）

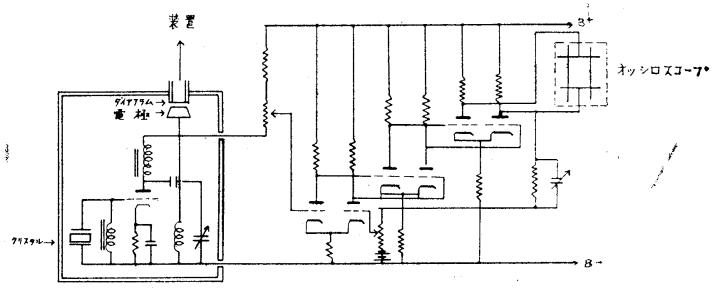

第12図 Lilly による回路（変位法）

た。压力に対応した容量の变化を電気的に取り出方方法 として共振回路を利用しているが、そのコンデンサー容 量 $C$ と共振周波数 $f$ とはとの平方根で反比例している から

$$
f=1 / 2 \pi \sqrt{C L}
$$

普通の場合、压力に対応子る容量 $C$ の变化分孞非常に 小さいので、高い共振周波数を使わなければならない。

\section{1 変位法}

4.1.1 LとCのみからなるもの

これは、Brookes-Smith(5) (1939年) によって高压測 定用（6000封度/平方时）に作られたもので高周波( $1 \mathrm{M}$ c/s）学利用している。この回路はコルピッツ発振定さ せ制御格子と陽極にコンデンサーを持つため固定周波数 で用いるのに便利である。

この発振回路と整流回路を可変コンデンテー劣持つ共 振回路で結合している第11図、压力が変化する事によっ て起る变位 $(0.0001$ 时で $20 \mu \mu F)$ は容量の既知の可变 コンデンサーで補正する事によりバランスされ、生力它 直読する。コンデンサーの変化容量が共振回路の総容量 に比較して小さいと動作範囲が共振曲線の非常に小さい 部分定しめ直線性を示す。

\section{1 .2 水晶発浱回路を利用したもの}

発脤によって高い周波数の共振波它利用与ると、その 精度から高い安定性が要求され、水晶を利用したものが 作られた。Lilly(6) (1942年)によって動脈定流れる血 液の圧力を直接測定するために作られた。それ注利共 振利用の水晶発浱器でピーアス回路といはれるもので市 る。(第12図) 


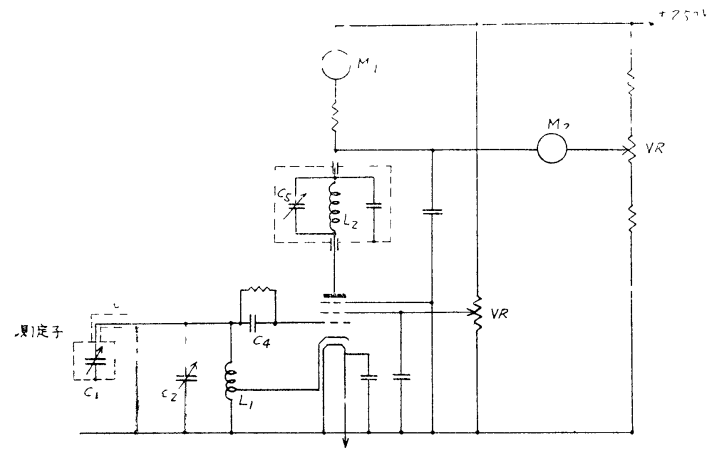

第13図 cook 汇よる回路（变位法）

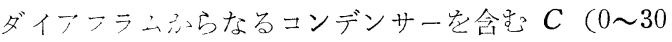
$\left.f^{\prime} \mu \mathrm{F}\right)$ 乙 $L$ の共振回路を陽極側に入れてある。しかし こ机憕振周佊数を決定するためのものてはなく、ただ 発振周波数に対して共振回路のリアクタンスを变化する 事により発振強度が調整出来るためである。压力の変化 をコンデンサーの容量变化として見ると晹極電圧を変化

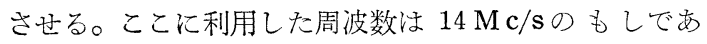
り、410ボルトの電源肎約 50 ボルトに下けて与元てい る。

電源に対する安定度注発振山力が小さい注ど良好てあ る。増幅器は一般的な双 3 極管による差動増幅器を 3 段

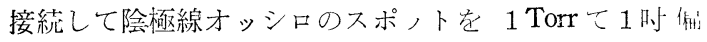
向させる感度を持ち、周波数带域を拡け又 1 时偏向につ き 200 Torr になるように感度を下けて使うときは帰逞 量て調節されている。この回路構成て発振管及ひ発振回 路堂測定子の容量变化をさせるコンデンサー部分と在同 一の容器に入れ、増幅器部分とケーブルで結びその長さ 坊測定量に影響しないように考慮されている。（ケーブ ルの長さは20フィートなてならいくらてもよい。)

\subsection{3プリッチ回路在応用したもの}

コンデンサーの容昂变化总周波数の変化としてとりた し、簡単加つ精度のよいものが $\mathrm{Cook}^{(7)}$ (19j3年) によ 質量分析計の資料ガ大覌入系用として則定範围 $10^{-3}$ Torr から 10-1Torr 屯て $05 \times 10^{-3}$ Torr より良い粘度 て䐓定出来る主のが价られた。第13図

霍子絬合発振回路空利用したものて陰極、制御格子、 遮蔽格子の 3 電極て発振回路が構成され（ハートレー回 路）陽極から出力安取り出している。遮蔽格子により晹 極回路之発㧓回路とが遮萳され、その間に静電的な結合 は無く、陽極電压が高ければほとえ゙゙電子流は陽極に洼 乙晹㥛焦街加ら電力在取り出正事加出来る。

したがってこの回路は発振部と負荷とが隔離された縟

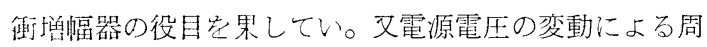
波数の变化尼少ない。発振器の周波数流ダイアフラム足

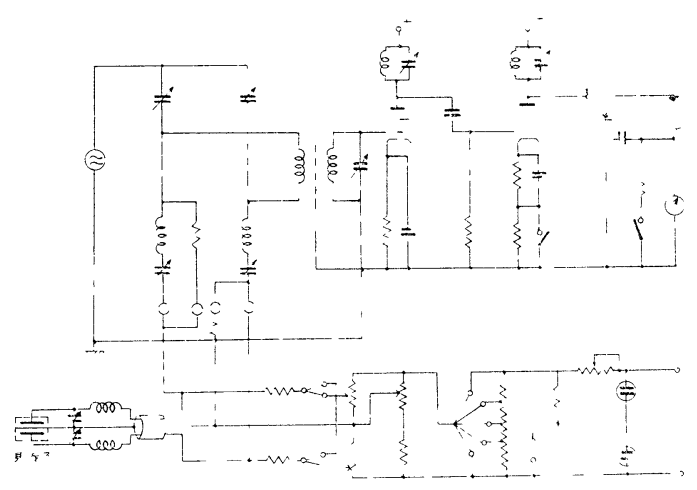

第14図 零位法による回路の代表例

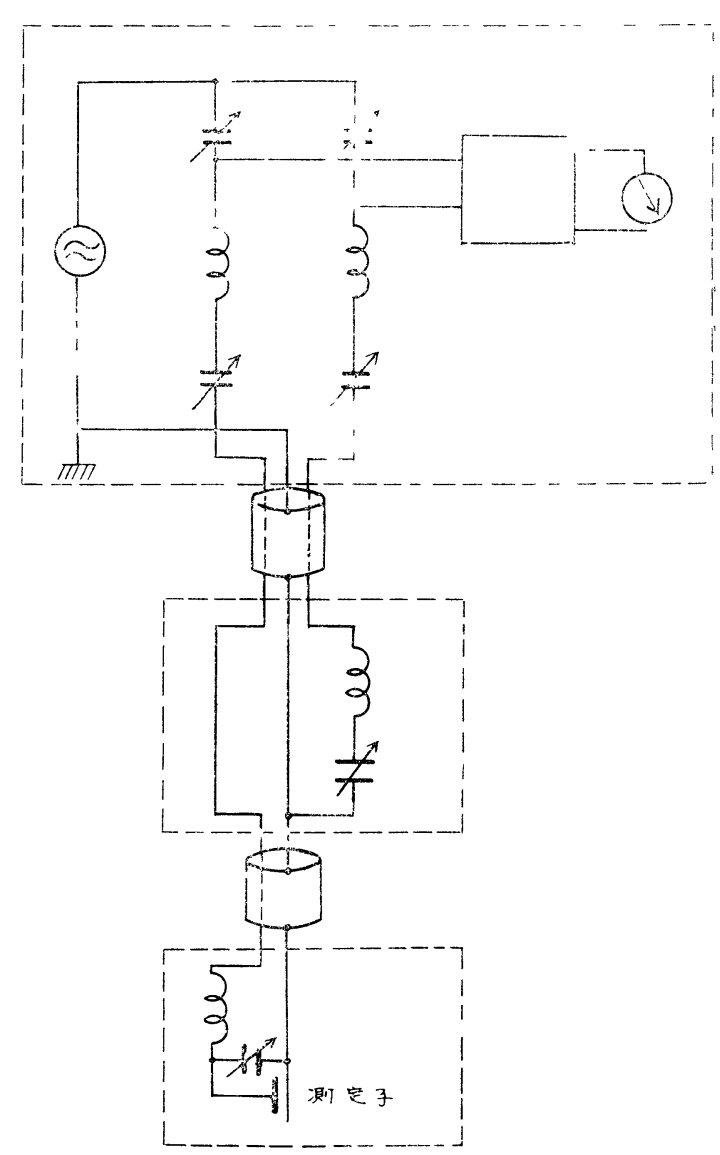

第15図 測定子のコンデンサー定䈯き換えた回路 (変位法)

はさむ任力差によって決まり、10-1 Torr の圧力差て 6.6 $\mathrm{M} \mathrm{c} / \mathrm{s}$ から $5.8 \mathrm{Mc} / \mathrm{s}$ に減少する。これは測定子コン デンサーC $C_{1}$ の変化によって起きる。その周波数は吸収 型周波数計として働く $L_{2}$ と $C_{5}(15 \mu \mu \mathrm{F})$ で測定さ れ、この場合共振回路の「引込久現象」を起し誤差を生 じるのを防ぐた第 2 高調波に共振するようにしてあ 
る。このように共振している時には回路のインピーダン スは増大するので最も陽極電流の少ない点を $M_{1}$ (フル スケール $5 \mathrm{~mA}$ ) で読み、かつ微調整用として高感度の ガルバノメーター $M_{2}$ をもった共振回路をブリッヂの 辺に入れて平衡させる。この時 $C_{5}$ の変化が目盛の中央 で共振曲線のピークになり、その最高值が $M_{2}$ を通る ようにブリッヂを調整する。この精度は非常に高く、こ れに加えて其振回路の $Q$ 妾高くしておくと其振曲線を 鋭くさせる事が出来る。

\section{2 零位法}

ここに述べるものはフィリップスの opstelten ${ }^{(8)}$ (19 60年) によって行なる秃た質量分析計用のものである。

ダイアクラムと電極で構成されたコンデンサーはそれ ぞれ 1 個のコイルと直列になってホイストン・ブリッヂ の 2 辺になっている。他の 2 辺はコンデンサーのみから 出来ている。このブリッヂに $1 / 2 \mathrm{M} \mathrm{c} / \mathrm{s}$ の高周 波電圧を かけ直列共振するようにし、不平衝状態になった時の信 号はやはり、1/2 Mc/sに同調してある増幅器によって増 幅され検知、指示される。この回路の構成は第 14 図に 示す。

増幅器の出力を指示させた後、ダイアフラムに直流電 源から静電的な力を加え、ダイアフラムを圧力が零であ った位置にもどして、この時の電圧で圧力を知るように なっている。しかし压力測定で 1 Torr.上上になって来 るとガス含生側に電压をかけると電極上に放電が起 る。

この場合には標準となるコンデンサーで置き換えたブ リッヂの一巡を作って平衝させるようにする(第15図)。

\section{5. 容量変化として検出する型の代表例}

4.2 で 1 部分述べたが、ここに代表例として説明す る(8)。これは質量分析計用に作られたもので $10^{-5}$ Torr から 10 Torr の測定範囲它持ち、測定子は厚さ 20 ミクロ ンのステンレスで作ったダイアフラムによって 2 つの部 屋に区切られている。ダイアフラムの両面から 25 ミク ロン離れた所にそれぞれ平らな電極面があり、ダイアフ

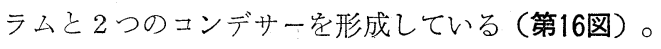

測定子全体はステンレスで作り、絶縁を必要とする所 はセラミックスで、久導体の接触を防ぐために小さなガ ラス片を使っている。

測定子のコンデンサーはコイルと直列に結び、2辺を 作り、他の辺恪 1 個のコンデンサーでホイストン・ブ リッデ胥構成している。ここに $1 / 2 \mathrm{M} \mathrm{c} / \mathrm{s}$, 数ボルトの 電压它発振器から与えて、測定子とコイルが直列共振す るようになっている。このためインピーダンスは非常に

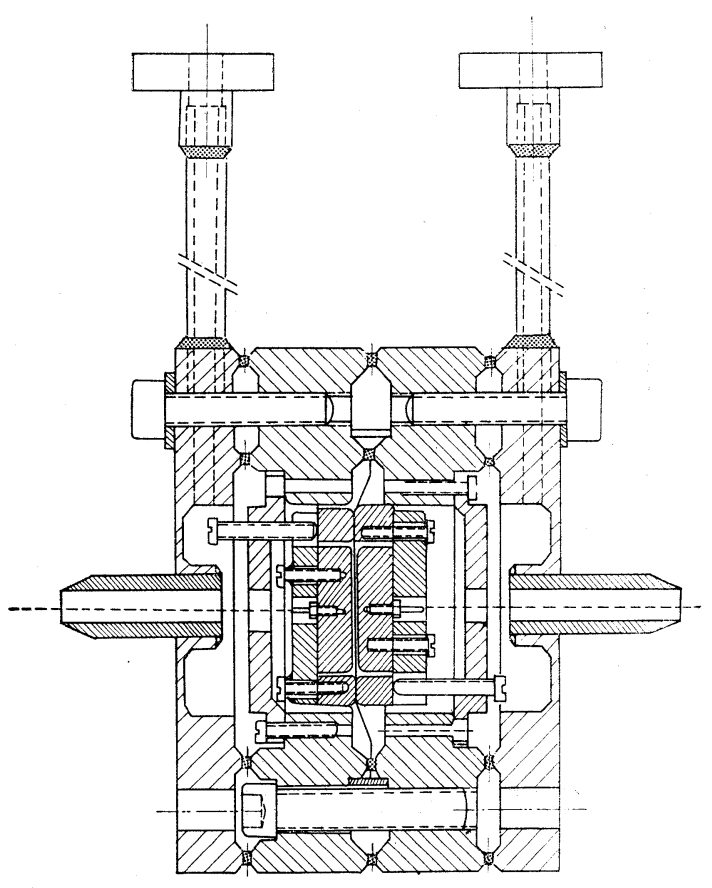

第16図 容量型測定子の代表例 (フィリップス社に て試作したもの)

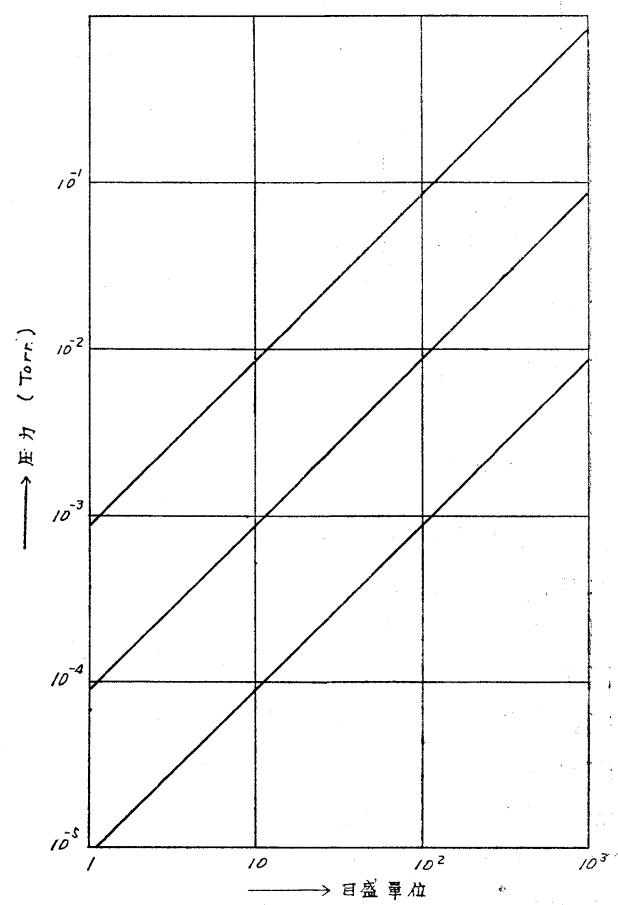

第17図 感度曲線 (零位法)

小さくなって測定子に結ぶケープルによって起る容量の 僅かな変化は全体として無視出来、ケーブル它長くする 事が出来る。 


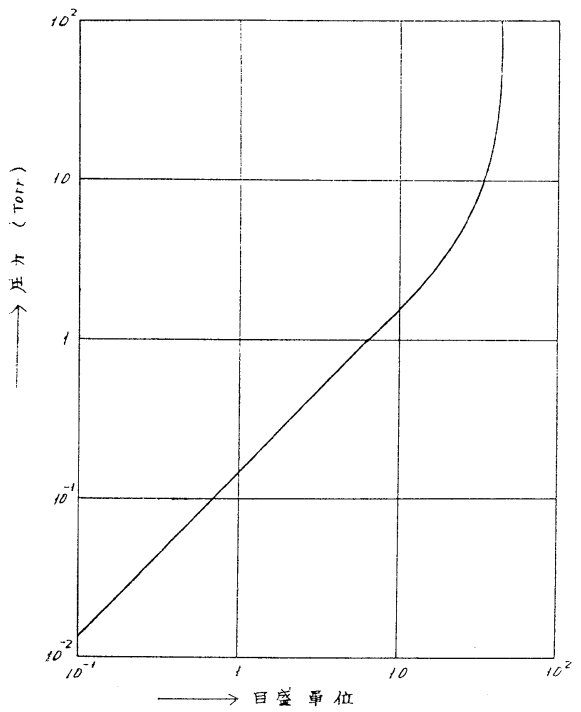

第18図 感度曲線（変位法）

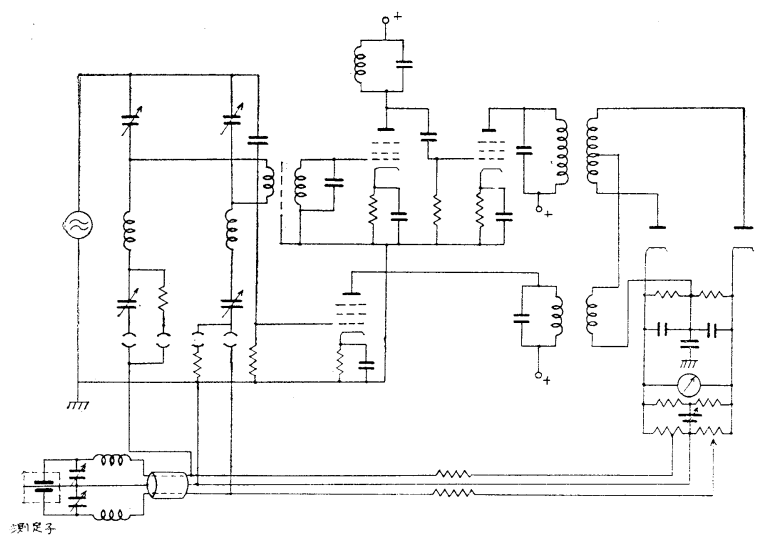

第19図 自動記録を行う場合の回路

測定子に圧力差が生じると、ブリッヂは不平衝な状態 となり、その状態に比例したブリッヂの不平衡電圧を $1 / 2 \mathrm{M} \mathrm{c} / \mathrm{s}$ に同調した増幅器に与える。この増幅器は陽極 そ高インピーダンスを持つ共振回路を置き、2段増幅し た後、整流してメーターにより指示する（第14図）。

測定子は一方の部屋をペニングゲージにより 10-7 Torr に非気し、他の部屋に测らうとするガスを入れ、 ダイアフラム変位させる。測定時は常に両電極に $U 。$ なる電圧を与えておき、ダイアフラムの变位と等しい力 毒静電的に加光、ダイアフラムを圧力“零の位置にもど 守。このとき、真空側の電圧堂減し、ガスを含导側の電 王を増す。この值を $U$ とすると、压力と $U$ と注線形 の比例関係となり、Uを正確に読む事により压力安知り

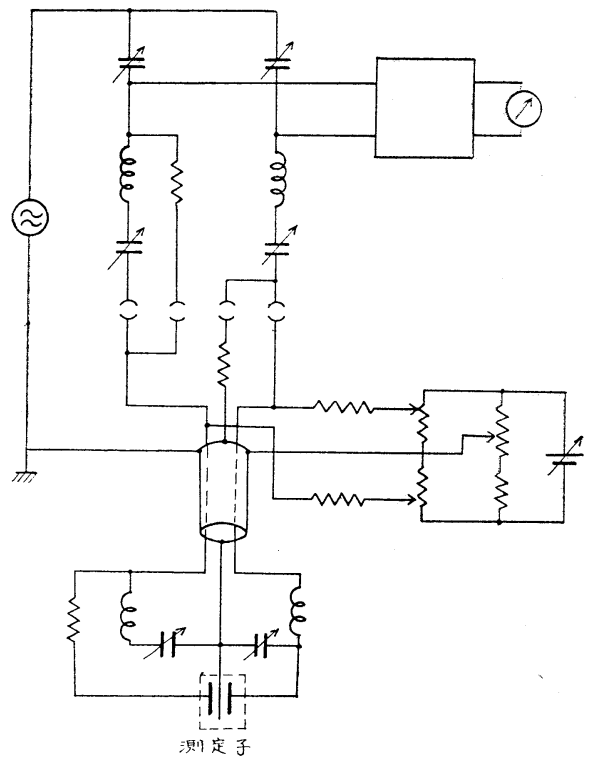

第20図 ガスの吸着属による影響を考慮した回路 (零位法)

得る。

圧力につり合う静電的な力は(18)で示した。第17図に 感度曲線を示す。

このようにして $10^{-5}$ Torr から 1 Torr 宋での測定 が出来るが 1 Torr 以上となると電極上電圧がかか っているのでガスにより気体放電を起す。この範囲で 測定するために測定子のこの部分を標準となるコンデ ンサーで置き換える。压力によりダイアフラムが変位 すると、標準となるコンデンサーでブリッヂを平衝状 態にし、その読み汃ら圧力を知り得る（第15図, 第18 図)。

この測定子を用いて自動記録を行う場合は同じ周波 数で基準となる電圧を作り、圧力の変化に応じた電圧 に重畳して、和と差の直流電圧を取り出し、両電压を比 較して指示させる（第19図）。

分子量の大きな物質の蒸気圧を測るために法測定子を 常に $150^{\circ} \mathrm{C}$ に加熱しておく。

正確な測定孛しようとする時には安定したサーモスタ ットの中に測定子を入るとよい（精度約 1\%）

$10^{-5}$ Torr の圧力は測定子の容 量で $10^{-4} \mathrm{pF}$, ダイフ フラムの变位は $0.25 \AA$ となる。又原理的に注気体の性 質には関係しない䉪である。しかし複雑な現象が起る。 電極面上に吸着さ机た気体の吸着層の誘電率は気体に比 較して高く、測定子の容量をかなり变える。測定子容量 の相対的変化法非常に小さい $\left(10^{-3}\right.$ Torr で 10-4 位) か ら、この現象による誤差は大きい、吸着属による容量の 
変化き静電引力にはほとえど影響索与えないので（この 場合のコンデンテーの容最は $100 \mathrm{pF}$ 位) 真空にした側 の測定子の容量をブリッヂに入れ、前と同じくダイアフ ラムの零位置を指示させる。

一方静電的な力は両面か同倳に加えると前と同じよう に直線目盛る得るが感度は半分になる。(第20図)

六弗化ウランのような反応性の気体の場合に核測定子の ガス觉入れる部屋に電極を作らずセラミックスやガラス 学使わないで他の側穵ブリッヂに入れ容量の变化を標準 のコンデンサーで補正する。これ注 10〜10-3 Torr の 範囲で可能で西り直線性の目盛となる。他の方法は1方 の部屋にアルゴン等の気体を測定ガスより少し高い圧力 で導入しダイアフラムを静電的に引きもどして行なわれ る。この場合浪非直線性の目盛となる。

以上の方法に扎て、ダイアフラムを引きもどす方法 堂応用する時㑑自記々録定行う事が出来る。又サーボモ ーターを標準のコンデンサーと連結しても同様である。

又ホイストンブリッヂの平衝のズレを直接に自記々録 方る事も出来るが堌幅器の安定度に左右された測定結果
となる。

\section{[交献 $]$}

(1) W. A. Bassali : Z. Angew. Math. u. Mech., 40 (1960) 493-507

(2) J. C. Lilly, V. Legallais and R. Cherry : $J$. Appl. Phps. . 18 (1947) 613-628

(3) H.W. Drawin : Advances in Vac. Sci. Tech., (1960) $20-24$

(4) D. C. Pressy : J.Sci. Instrum. , 30(1953)20-24

(5) C. H. W. Brookes-Smith : J. Sci. Instrum., 16 (1939) $361-366$

(6) J. C. Lilly : R.Sci. Instrum., 3 (1942) 3437

(7) D. B. Cook and C. J.Danby : J.Sci. Instrum., 30 (1953) $238-240$

(8) J. J. Opstelten et N. Warmoltz : Advances in Vac. Sci.Tech., (1960) 295-298

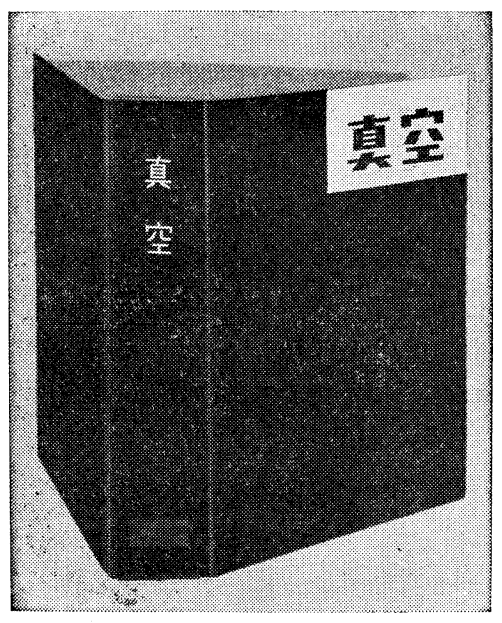

\section{合本用ファイルをご利用下さい}

ピン 1 本で簡単に、そして美麗に、一カ年分を 合本できる独特のものです。

書棚を飾るにも、本誌の整理にも、是非必要な ファイル。

頒価 1 部 170 円 送料 60 円

お申込又先

東京都中央区日本橋兜町 3 の 5 三共ビル内

真空協会合本係

電 $\quad(800) \quad 4 \quad 3227$ 番 